\title{
Frequent loss of p19 ${ }^{\mathrm{INK} 4 \mathrm{D}}$ expression in hepatocellular carcinoma: Relationship to tumor differentiation and patient survival
}

\author{
ASAHIRO MORISHITA $^{1}$, JIAN GONG ${ }^{2}$, AKIHIRO DEGUCHI $^{2}$, JOJI TANI ${ }^{2}$, HISAAKI MIYOSHI $^{2}$, \\ HIROHITO YOSHIDA ${ }^{2}$, TAKASHI HIMOTO ${ }^{2}$, HIROHITO YONEYAMA ${ }^{2}$, HIROHITO MORI $^{2}$, \\ KIYOHITO KATO $^{2}$, KAZUTAKA KUROKOHCHI ${ }^{2}$, KAZUSHI DEGUCHI ${ }^{2}$, KUNIHIKO IZUISHI $^{3}$, \\ YASUSHI SUZUKI ${ }^{3}$, YOSHIO KUSHIDA ${ }^{4}$, REIJI HABA ${ }^{4}$, HISAAKI IWAMA ${ }^{5}$, \\ SEISHIRO WATANABE ${ }^{2}$, JEANINE D'ARMIENTO ${ }^{1}$ and TSUTOMU MASAKI $^{2}$
}

\author{
${ }^{1}$ Department of Medicine, College of Physicians and Surgeons, Columbia University, New York, NY 10032, USA; \\ Departments of ${ }^{2}$ Gastroenterology and Neurology, ${ }^{3}$ Gastroenterological Surgery, ${ }^{4}$ Diagnostic Pathology, and ${ }^{5}$ Information \\ Technology Center, Kagawa University School of Medicine, Miki-cho, Kita-gun, Kagawa 761-0793, Japan
}

Received May 12, 2011; Accepted June 14, 2011

DOI: $10.3892 /$ or.2011.1452

\begin{abstract}
INK} 4 \mathrm{D}}$ belongs to the family of cyclin-dependent kinase inhibitors (CdkIs) that target the cyclin-dependent kinases and inhibit their catalytic activity. The role of $\mathrm{p} 19^{\mathrm{INK} 4 \mathrm{D}}$ in cell cycle progression in hepatocellular carcinoma (HCC) is poorly characterized. The aim of this study was to examine the expression of $\mathrm{p} 19^{\mathrm{INK} 4 \mathrm{D}}$ in various liver diseases including HCC and to assess its clinical significance in HCC. We examined the expression of $\mathrm{p} 19^{\mathrm{INK} 4 \mathrm{D}}$ by immunohistochemistry in 81 cases of various liver diseases, including 51 HCCs. We analyzed the relationship among p19 ${ }^{\text {INK4D }}$ expression in HCC in combination with histopathological stage, differentiation, several histopathological factors of possible prognostic value and patient survival. Immunohistochemical analysis revealed the frequent loss of $\mathrm{p} 19^{\mathrm{INK} 4 \mathrm{D}}$ expression consistent with the differentiation of HCC. The loss of $\mathrm{p} 19^{\mathrm{INK} 4 \mathrm{D}}$ expression was shown to be associated with a poor prognosis by analyzing clinicopathological features. In conclusion, we found that loss of p19 ${ }^{\text {INK4D }}$ protein was frequent in HCC, especially in poorly differentiated $\mathrm{HCC}$, suggesting that $\mathrm{p} 19^{\mathrm{INK} 4 \mathrm{D}}$ may play a role in the differentiation of HCC. Furthermore, expression of p19 ${ }^{\text {INK4D }}$ may be an effective predictor of clinical behavior in HCC, and therefore, a new prognostic marker for HCC.
\end{abstract}

Correspondence to: Dr Asahiro Morishita, Department of Medicine, College of Physicians and Surgeons, Columbia University, New York, NY 10032, USA

E-mail: am2925@columbia.edu

Abbreviations: Cdk, cyclin-dependent kinase; CdkI, cyclindependent kinase inhibitor, $\mathrm{CH}$, chronic hepatitis; $\mathrm{HCC}$, hepatocellular carcinoma; NL, normal liver

Key words: p19 ${ }^{\mathrm{INK} 4 \mathrm{D}}$, hepatocellular carcinoma, differentiation, Cdk

\section{Introduction}

Hepatocellular carcinoma (HCC) is one of the major causes of cancer-related death due to its high frequency and poor prognosis. In spite of the development of various treatments for HCCs, such as, surgical resection and transarterial chemoembolization (TACE), percutaneous ethanol injection (PEI) and percutaneous radiofrequency (RFA), the 5-year survival rate for all stages of HCC has remained less than $60 \%(1,2)$. In general, prognostic evaluation is mainly based on the clinical factors, such as, histopathological stage, clinical stage, tumor size, and tumor numbers. In addition, some studies $(3,4)$ including our reports $(5,6)$ have suggested that other factors, such as the molecular characteristics of the tumor, may offer novel approaches to the identification of groups of patients that could benefit from more aggressive treatment.

Cyclins, cyclin dependent kinase (Cdk) and Cdk inhibitors (CdkIs) are frequently altered in human cancers (7-9). In mammalian cells, to date, at least 2 distinct families of CdkIs are known. The inhibitor of Cdk4 (INK4) family consists of $\mathrm{p} 16^{\mathrm{INK} 4 \mathrm{~A}}, \mathrm{p} 15^{\mathrm{INK} 4 \mathrm{~B}}, \mathrm{p} 18^{\mathrm{INK} 4 \mathrm{C}}, \mathrm{p} 19^{\mathrm{INK} 4 \mathrm{D}}$, which specifically inhibit cyclin D-related kinase activity by binding to Cdk4 or Cdk6 (10-14). The other known CdkI family, the p21 family, consists of $\mathrm{p} 21^{\mathrm{CIP} / \mathrm{WAF} 1}, \mathrm{p} 27^{\mathrm{KIP1}}$, and $\mathrm{p} 57^{\mathrm{KIP} 2}$, which are general inhibitors of the $\mathrm{G} 1$ to $\mathrm{S}$ transition in the cell cycle $(13,15)$. At clinical involvement, the loss of the expression of KIP family members' $\mathrm{p} 21^{\mathrm{CIP} 1}$, and $\mathrm{p} 27^{\mathrm{KIP} 1}$ has recently been shown to be associated with poor prognosis for various human cancers $(16-21)$. $\mathrm{p} 57^{\mathrm{KIP} 2}$ is also correlated with the differentiation and prognosis for patients with $\mathrm{HCC}(5)$.

$\mathrm{p} 16^{\mathrm{INK} 4 \mathrm{~A}}$ and $\mathrm{p} 19^{\mathrm{INK} 4 \mathrm{D}}$, members of the INK4 family, are the most extensively studied in various human cancers including HCC with respect to the clinical significance $(3,4,12,14,22)$. However, very little data are available on the relationship between $\mathrm{p} 19^{\mathrm{INK} 4 \mathrm{D}}$ and human malignancies. The clinical significance of $\mathrm{p} 19^{\mathrm{INK} 4 \mathrm{D}}$ expression also remains unknown in human cancers, including HCC. Therefore, in this study, we examined the expression of $\mathrm{p} 19^{\mathrm{INK} 4 \mathrm{D}}$ and analyzed the relation- 
ship between its expression and clinicopathological features including the prognosis in HCC.

\section{Materials and methods}

Patients. Between 1987 and 2006, liver biopsy specimens were obtained from 30 patients with chronic hepatitis $(\mathrm{CH})$ and 51 patients with $\mathrm{HCC}$ at Kagawa Medical University, Japan. Of these 30 patients with $\mathrm{CH}, 27$ patients were positive for $\mathrm{HCV}$ RNA, and 3 patients were positive for the hepatitis B antigen. Six patients were classified in F1, 7 patients in F2, 8 patients in F3, 8 patients in F4 according to Desmet's classification (23). Seven normal livers (NLs) were obtained by surgical resection of liver metastasis of colon cancer. Normal controls had no hepatitis virus-associated liver disease. HCC specimens were obtained from 6 patients by surgical resection and the others were obtained by needle biopsy before therapy. Thirty-seven patients were male, and 14 patients were female. The mean age of these patients was 62.9 \pm 7.2 (mean $\pm \mathrm{SD}$; range, $44-75$ years). Forty-five patients with HCC were positive for HCV-RNA, and 6 patients with $\mathrm{HCC}$ were positive for HBsAg. According to the pathologic tumor-nodes-metastasis (pTNM) classification proposed by the International Union Against Cancer and the American Joint Committee on Cancer (UICC, 1997) (24), 9 patients were in stage I, 15 in stage II, 8 in stage III, and 19 in stage IV. Histological grade of HCC was determined as well differentiated, moderately differentiated or poorly differentiated according to the criteria of the International Working Party (24). The numbers of patients with well-, moderatelyand poorly differentiated HCCs were 16,30 and 5, respectively (Table I). Informed consent was obtained from each patient prior to participation.

Antibodies. We examined the expression of $\mathrm{p} 19^{\mathrm{INK} 4 \mathrm{D}}$ in $\mathrm{HCC}$ by immunohistochemistry using a specific antibody (Santa Cruz Biotechnology, Inc., Santa Cruz, CA). Immunohistochemistry was performed according to the method of our previous report (25), and the p19 ${ }^{\text {INK4D }}$ was detected by the avidin-biotinperoxidase complex (ABC) method using the Vectastain ABC Elite kit (Vector Laboratories, Inc., Burlingame, CA) and diaminobenzidine as the chromogen. In each case, the predominant staining pattern for $19^{\text {INK4D }}$ was classified as negative, cytoplasmic or nuclear, depending on the specificity of the immunoreactivity.

Immunohistochemistry. Sections ( $2 \mu \mathrm{m}$ thick) were cut from formalin-fixed paraffin-embedded tissue blocks, deparaffinized in xylene, rehydrated in graded series of ethanol solutions, and then mixed with a solution containing $0.5 \%$ hydrogen peroxidase to block the endogenous peroxidase activity. The sections were placed in a $10 \mathrm{nmol} / 1$ citrate buffer (pH 6.0) and processed at $500 \mathrm{~W}$ at $95^{\circ} \mathrm{C}$ for $10 \mathrm{~min}$ in a microwave oven (MR-M201 Microwave Processor; Hitachi, Tokyo, Japan). After washing with phosphate-buffered saline (PBS), the sections were processed for immunostaining by the $A B C$ method outlined above. Primary incubation was performed overnight at $4^{\circ} \mathrm{C}$ with monoclonal antibody against $\mathrm{p} 19^{\mathrm{INK} 4 \mathrm{D}}$. As a negative control, non-immune mouse IgG was substituted for the primary antibody. For signal amplification, the Renaissance TSA amplification kit (NEN ${ }^{\mathrm{TM}}$ Life Science
Products, Boston, USA) was used (26). Diaminobenzidine was used as the chromogen. All slides were examined and scored independently by two pathologists (T.M., S.W.) who were blinded to the pathological and clinical data assessed by a third observer (A.M.). For assessment of the expression of p19 ${ }^{\mathrm{INK} 4 \mathrm{D}}$, we categorized samples into two groups on the basis of the percentage of HCC cells demonstrating p19 ${ }^{\mathrm{INK} 4 \mathrm{D}}$ immunoreactivity, p19 ${ }^{\text {INK4D }}$ expression negative $(<50 \%)$ or p19 ${ }^{\text {INK4D }}$ expression positive $(>50 \%)$. The patterns of expression were classified into three groups (nuclear positive, cytoplasmic positive and negative staining pattern). Necrotic areas and edges of the tissue sections were not included in the counting to avoid possible immunohistochemical false-positives.

Statistical analysis. We performed statistical analysis of the relationship between the p19 $9^{\mathrm{INK} 4 \mathrm{D}}$ expression and clinicopathological parameters by means of the Fisher's t-test. The survival curves were plotted using the Kaplan-Meier method, and differences were evaluated by a log-rank test. In addition, to identify independent predictors of patients' prognosis, we performed multivariate analysis, using the Cox proportional hazards model. Differences were considered significant when $\mathrm{P}<0.05$. All statistical analyses were performed using the computerassisted StatView program (SAS Institute, Cary, NC, USA).

\section{Results}

p19 $9^{I N K 4 D}$ expression in NL, CH and liver cirrhosis. Representative immunostaining of p1 $^{\text {INK4D }}$ in $\mathrm{CH}$ are shown in Fig. 1A and B and of liver cirrhosis in Fig. 1C and D. Fibrotic stages of Fig. 1A and B were F2, and of Fig. 1C and D were F4 according to Desmet's classification. The localization of p19 ${ }^{\text {INK4D }}$ in F2 (Fig. 1A and B) stages of fibrosis was observed in the hepatocyte nuclei (arrows). Interestingly, p19 ${ }^{\mathrm{INK} 4 \mathrm{D}}$ was detected in all 30 patients with $\mathrm{CH}$ or cirrhosis in hepatocytes (Table I). In liver cirrhosis, the expression of p19 $9^{\text {INK4D }}$ was observed in 7 of 9 cases with liver cirrhosis and was detected in the cytoplasm of hepatocytes, but not in the nucleus (F4; Fig. 1C and D). On the other hand, p19 ${ }^{\mathrm{INK} 4 \mathrm{D}}$ was expressed not only in the nucleus, but also in the cytoplasm in 2 of 9 cases of liver cirrhosis (data not shown). The expression of p19 ${ }^{\text {INK4D }}$ was also detected in the nucleus of hepatocytes in all NLs examined in this study (data not shown).

p19 ${ }^{I N K 4 D}$ expression in malignant liver tissues. As shown in Table II, the immunohistological study of $\mathrm{p} 19^{\mathrm{INK} 4 \mathrm{D}}$ identified no staining in 19 of 51 HCCs (37.3\%) and 32 cases expressed p19 $9^{\text {INK4D }}(62.7 \%)$. In well-differentiated HCCs, 13 of 16 tumor samples stained positive for nuclear $\mathrm{p} 19^{\mathrm{INK} 4 \mathrm{D}}(81.3 \%$; Fig. 2A-C), and the remaining cases were negative for staining (18.7\%). In moderately differentiated HCCs, the expression of p19 ${ }^{\text {INK4D }}$ was detected in 17 of 30 cases (56.7\%), while the remaining 13 cases $(43.3 \%)$ were p19 ${ }^{\mathrm{INK} 4 \mathrm{D}}$-negative (Fig. 2D-F). Among the 5 poorly differentiated HCCs, p19 ${ }^{\mathrm{INK} 4 \mathrm{D}}$ was not detected in any cases $(0 \%)$. p19 $9^{\mathrm{INK} 4 \mathrm{D}}$ expression and clinicopathological variables were correlated by univariate analysis (Table II). Loss of $\mathrm{p} 19^{\mathrm{INK} 4 \mathrm{D}}$ expression was significantly associated with histological grade and advanced TNM stage. However, no significant relationship was seen between p1 $^{\text {INK4D }}$ expression and gender, age, infection with hepatitis $\mathrm{B}$ or $\mathrm{C}$ virus. 

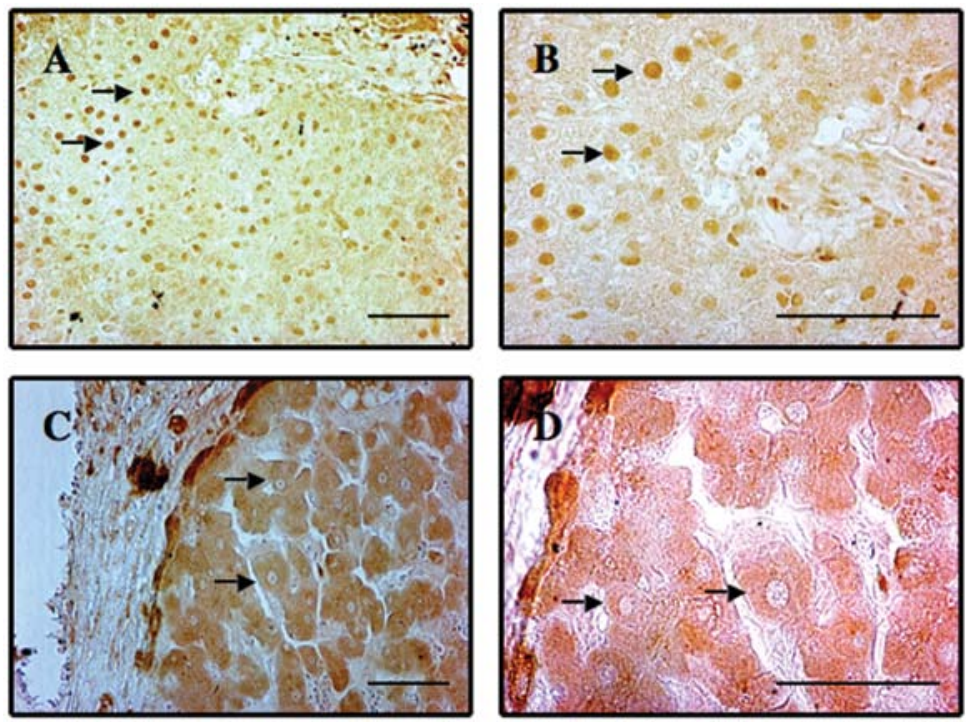

Figure 1. Immunohistochemistry of p19 ${ }^{\mathrm{INK} 4 \mathrm{D}}$ in chronic hepatitis (A and B) and liver cirrhosis (C and D). Fibrosis stages indicated in (A, B) and (C, D) were grades F2 and F4 according to Desmet's classification, respectively. Staining for $\mathrm{p} 19^{\mathrm{INK} 4 \mathrm{D}}$ in chronic hepatitis was seen in the hepatocellular nucleus (arrows in $\mathrm{A}$ and B). Expression of p19 ${ }^{\mathrm{INK} 4 \mathrm{D}}$ in liver cirrhosis was positive for p19 ${ }^{\mathrm{INK} 4 \mathrm{D}}$ staining in the hepatocellular cytoplasm but not in the hepatocellular nucleus (arrows in C and D). The original magnifications are x100 in (A and C) and x200 in (B and D). Bars on the lower right of pictures, $50 \mu \mathrm{m}$.

\section{Well differentiated Moderately differentiated Poorly differentiated}
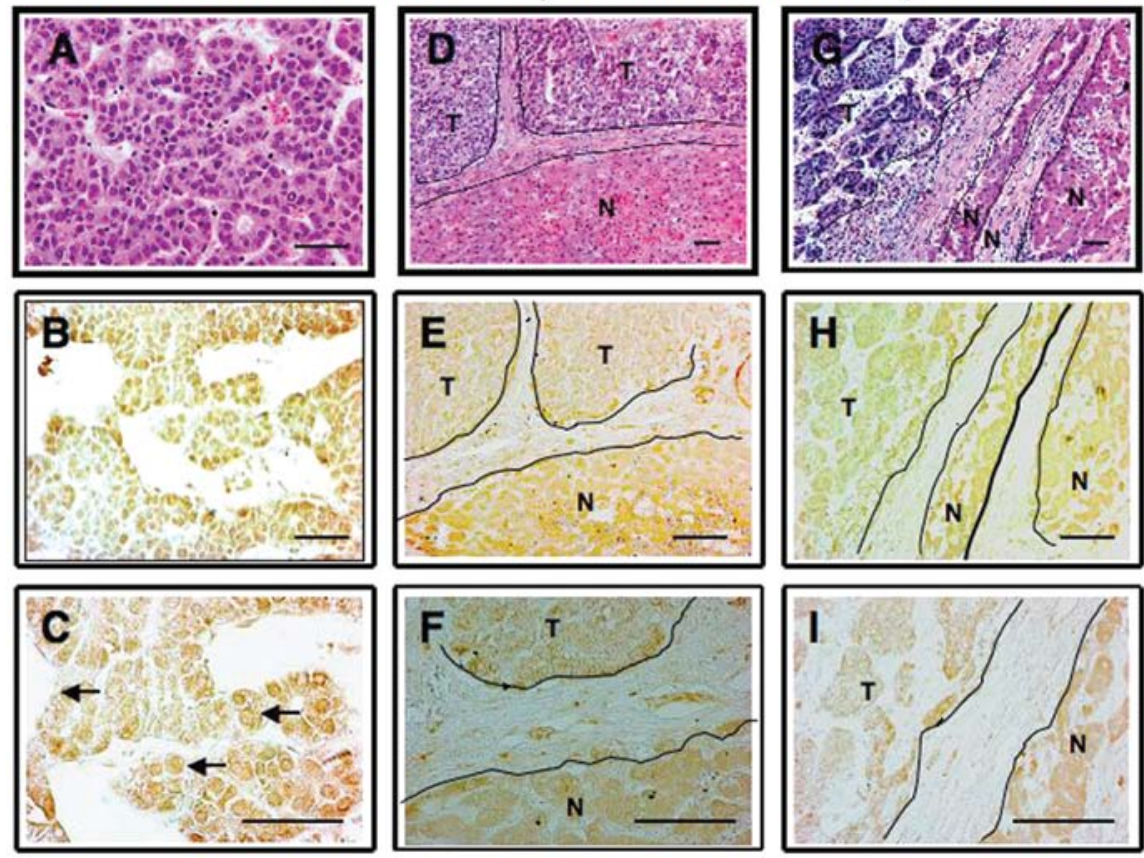

Figure 2. Immunohistochemistry of p19 ${ }^{\mathrm{INK} 4 \mathrm{D}}$ in well- (B and C), moderately- (E and F), and poorly-differentiated (H and I) HCCs. (A, D and G) show hematoxylin and eosin staining of the section adjacent to (B, E, and H), respectively. (C, F, and I) represent the higher magnification of the sections of (B, E, and $\mathrm{H}$ ), respectively. T and N indicate HCC and non-tumorous cirrhotic tissues, respectively. The expression of p19 ${ }^{\text {INK4D }}$ in most well-differentiated HCCs was localized in the nuclei of cancer cells (arrows). Conversely, its expression in most moderately- and poorly-differentiated HCCs was not detected. The scar indicates the boundary between $\mathrm{N}$ and $\mathrm{T}$ tissues. The original magnifications in (A, B, E and H), (D and G), and (C, F and I) are x100, x0 and x200, respectively. Bars on the lower right of pictures, $50 \mu \mathrm{m}$.

Prognostic significance of $p 19^{I N K 4 D}$. In addition, we analyzed the prognostic significance of $\mathrm{p} 19^{\text {INK4D }}$ on patient survival. Survival analysis in HCC was performed by using the KaplanMeier method, and the differences were evaluated by the long-rank test. The tumors were divided according to $\mathrm{p} 19^{\mathrm{INK} 4 \mathrm{D}}$ expression into the $\mathrm{p} 19^{\mathrm{INK} 4 \mathrm{D}}$-positive $(\mathrm{n}=32)$ and $\mathrm{p} 19^{\mathrm{INK} 4 \mathrm{D}}$ - negative groups $(\mathrm{n}=19)$. Patients with $\mathrm{p} 19^{\mathrm{INK} 4 \mathrm{D}}$-negative HCC had a significantly worse prognosis than those with $\mathrm{p} 19^{\mathrm{INK} 4 \mathrm{D}}$ positive HCC ( $\mathrm{P}=0.0179$; Fig. 3).

Multivariate analysis using the Cox proportional hazards models. Among age, gender, infection, histological grade, 
Table I. Relationship between expression of $\mathrm{p} 19^{\mathrm{INK} 4 \mathrm{D}}$ in various liver diseases and histological features.

\begin{tabular}{|c|c|c|c|c|c|}
\hline \multirow[b]{2}{*}{ Histology } & \multirow[b]{2}{*}{$\mathrm{n}$} & \multicolumn{3}{|c|}{ p19 $9^{\text {INK4D }}$ staining pattern } & \multirow[b]{2}{*}{ P-value } \\
\hline & & Negative (\%) & Nuclear (\%) & Cytoplasmic (\%) & \\
\hline NL & 7 & $0(0)$ & $7(100)$ & $0(0)$ & \\
\hline $\mathrm{CH}^{\mathrm{a}}$ & 30 & $0(0)$ & $23(76.7)$ & $7(23.3)$ & \\
\hline $\mathrm{F} 1$ & 6 & $0(0)$ & $6(100)$ & $0(0)$ & $<0.0001^{\mathrm{b}}$ \\
\hline $\mathrm{F} 2$ & 7 & $0(0)$ & $7(100)$ & $0(0)$ & \\
\hline F3 & 8 & $0(0)$ & $8(100)$ & $0(0)$ & \\
\hline F4 & 9 & $0(0)$ & $2(22)$ & $7(78)$ & $0.0009^{c}$ \\
\hline
\end{tabular}

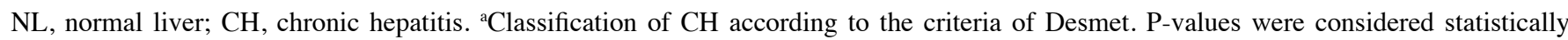
significant if $\mathrm{P}<0.05 .{ }^{\mathrm{b}} \mathrm{P}$-value was three-sided (Kruskal-Wallis test). ${ }^{\mathrm{C}} \mathrm{P}$-value for F1/2/3 vs. F4 was two-sided (Mann-Whitney U-test).

Table II. Relationship between p19 ${ }^{\text {INK4D }}$ immunoreactivity in HCC and clinicopathological features.

\begin{tabular}{|c|c|c|c|c|c|}
\hline & \multirow[b]{2}{*}{$\mathrm{n}$} & \multicolumn{3}{|c|}{ p19 staining status (\%) } & \multirow[b]{2}{*}{ P-value } \\
\hline & & Positive $(+\mathrm{N} /+\mathrm{C})$ & Negative & Negative rate $(\%)$ & \\
\hline \multicolumn{6}{|l|}{ Gender } \\
\hline Male & 37 & $24(18 / 6)$ & 13 & 35.1 & \\
\hline Female & 14 & $8(7 / 1)$ & 6 & 42.9 & 0.7477 \\
\hline \multicolumn{6}{|l|}{ Age (years) } \\
\hline$<65$ & 27 & $19(14 / 5)$ & 8 & 29.6 & \\
\hline$\geq 65$ & 24 & $13(11 / 2)$ & 11 & 45.8 & 0.2607 \\
\hline \multicolumn{6}{|l|}{ Infection } \\
\hline $\mathrm{HCV}$ positive & 45 & $30(23 / 7)$ & 15 & 33.3 & \\
\hline HBsAg positive & 6 & $2(1 / 1)$ & 4 & 66.7 & 0.1792 \\
\hline \multicolumn{6}{|c|}{ Histological grade ${ }^{a}$} \\
\hline WD/MD & 46 & $30(22 / 8)$ & 16 & 34.8 & \\
\hline $\mathrm{PD}$ & 5 & 0 & 5 & 100 & 0.005 \\
\hline \multicolumn{6}{|l|}{ Tumor stage ${ }^{a}$} \\
\hline $\mathrm{I} / \mathrm{II}$ & 24 & $19(15 / 4)$ & 5 & 21 & \\
\hline III/IV & 27 & $13(10 / 3)$ & 14 & 52 & 0.041 \\
\hline
\end{tabular}

tumor stage and p19 INK4D expression, p19 ${ }^{\text {INK4D }}$ expression was only independent prognostic factors for patients' overall survival ( $\mathrm{P}=0.0201$; Table III).

\section{Discussion}

Deregulated cell cycle progression is one of the most significant alterations in cancer cells. The G1 to $\mathrm{S}$ phase transition is thought to be a key target of tumorigenesis, which is in part, negatively regulated by CdkIs. CdkIs regulate the progression of cell cycle by modulating the activity of Cdks (10-15). Inactivation of CdkI has been associated with neoplastic transformation in a large number of human epithelial tissues $(10,27)$.
To date, there is limited information about the relationship between $\mathrm{p} 19^{\mathrm{INK} 4 \mathrm{D}}$ and human malignancies. Bartkova et al reported that $\mathrm{p} 19^{\mathrm{INK} 4 \mathrm{D}}$ protein is abundant in spermatocytes of normal human adult testes, whereas virtually no p19 INK4D is detectable in testicular cancer, including the preinvasive carcinoma in situ stage (28). However, the expression of p19 ${ }^{\text {INK4D }}$ protein in HCC is not yet known. In the present study, therefore, we evaluated the expression of $\mathrm{p} 19^{\mathrm{INK} 4 \mathrm{D}}$ in various liver diseases including HCC.

The major finding of this study was the loss of p19 INK4D expression in a subset of HCCs, especially in poorly differentiated HCCs. Interestingly, p19 ${ }^{\text {INK4D }}$ was expressed in the nucleus of all cases of NL, CH and in the cytoplasm of liver cirrhosis, 
Table III. Multivariate Cox model analysis of overall survival.

\begin{tabular}{lccc}
\hline & \multicolumn{3}{c}{ Overall suvival } \\
\cline { 2 - 4 } & Hazard ratio & $95 \%$ CI $^{\mathrm{a}}$ & P-value \\
\hline Age $(\geq 65 /<65)$ & 1.289 & $0.617-2.692$ & 0.5 \\
Gender (female/male) & 1.149 & $0.502-2.631$ & 0.7429 \\
Histology (PD/WD and MD) & 1.596 & $0.462-5.519$ & 0.4601 \\
Infection (HBV/HCV) & 1.41 & $0.542-3.670$ & 0.4812 \\
Tumor stage (III-IV/I-II) & 1.466 & $0.633-3.393$ & 0.3717 \\
p19 & 2.56 & $1.159-5.656$ & 0.0201 \\
\hline
\end{tabular}

${ }^{\mathrm{a} C}$ Confidence interval. WD, well-differentiated hepatocellular carcinoma; MD, moderetely-differentiated hepatocellular carcinoma; PD; poorlydifferentiated hepatocellular carcinoma.

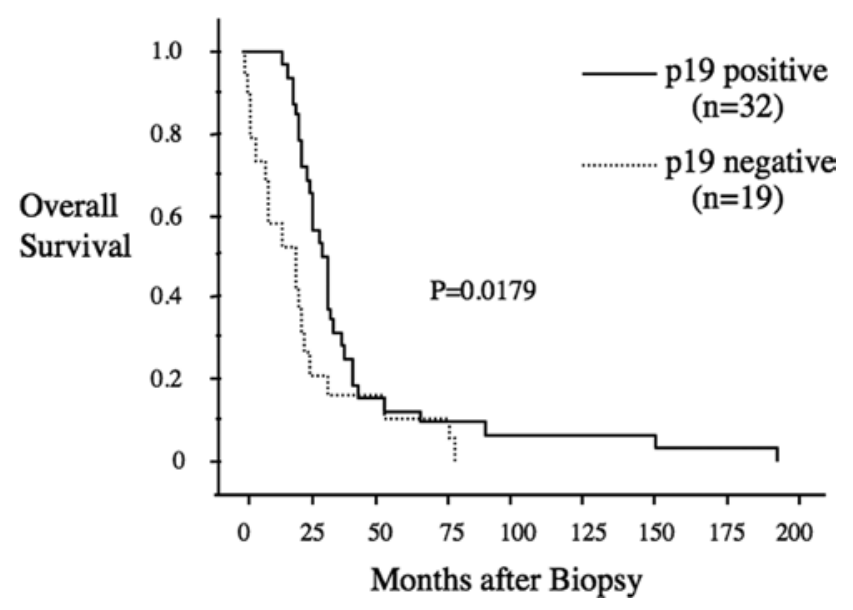

Figure 3. Kaplan-Meier curves of overall survival according to p19 expression indicating positive vs. negative staining in 51 patients with HCC. Time to death was significantly shorter in patients with $19^{\mathrm{INK} 4 \mathrm{D}}$-negative HCC than in those with p19 ${ }^{\text {INK4D }}$-positive HCC $(\mathrm{P}=0.0179)$.

but the loss of p19 $19^{\mathrm{INK} 4 \mathrm{D}}$ was detected in about $40 \%$ of HCCs, suggesting that it may be involved in hepatocarcinogenesis. In addition, the loss of $\mathrm{p} 19^{\mathrm{INK} 4 \mathrm{D}}$ in poorly differentiated HCCs was expressed at high frequencies compared to well- and moderately-differentiated HCCs. These results suggest that the down-regulation of $\mathrm{p} 19^{\mathrm{INK} 4 \mathrm{D}}$ is a common event in poorly differentiated HCCs. Therefore, the expression of p19 ${ }^{\mathrm{INK} 4 \mathrm{D}}$ represents a useful prognostic marker for survival in $\mathrm{HCC}$ patients.

The $\mathrm{p} 19^{\mathrm{INK} 4 \mathrm{D}}$ gene has been mapped to chromosome $19 \mathrm{p} 13.2$ (29). The results of previous studies indicating that $19 \mathrm{p} 13.2$ is deleted along with the frequent loss of heterozygosity ( $\mathrm{LOH})$ in various human cancers $(29,30)$ may help explain the loss of $\mathrm{p} 19^{\mathrm{INK} 4 \mathrm{D}}$ expression found in a subset of HCC in this study. In addition, a marked reduction of $\mathrm{p} 19^{\mathrm{INK} 4 \mathrm{D}}$ has been detected in various cancers, such as oral cancer, breast carcinoma and testicular cancer $(29,30)$. These previous reports support the importance of the finding in this study that reduced p19 ${ }^{\text {INK4D }}$ expression in HCC may be a critical step in patient survival.

The expression of $\mathrm{p} 19^{\mathrm{INK} 4 \mathrm{D}}$ in $\mathrm{HCV}$ - or $\mathrm{HBV}$-induced $\mathrm{CH}$ and cirrhosis was detected in all cases. $19^{\text {INK4D }}$ expression was not detected in about $40 \%$ cases of HCCs. The data suggest that the changes in $\mathrm{p} 19^{\mathrm{INK} 4 \mathrm{D}}$ expression are not influenced by hepatitis viral infection in the process of $\mathrm{HCC}$ from $\mathrm{CH}$, but its changes are influenced by the malignant process.

To date, $\mathrm{p} 19^{\mathrm{INK} 4 \mathrm{D}}$ has been reported to play an important role in the regulation of cell differentiation (31). To investigate the possible involvement of this protein in the differentiation of HCC, we analyzed the relationship between the level of p19 ${ }^{\text {INK4D }}$ expression and the histological grade of HCC. p19 ${ }^{\text {INK4D }}$ expression was reduced in poorly differentiated HCC, compared to well- and moderately-differentiated HCC. Utilizing immunohistochemical analysis of p19 ${ }^{\text {INK4D }}$, we observed an inverse correlation between $\mathrm{p} 19^{\mathrm{INK} 4 \mathrm{D}}$ expression and tumour aggressiveness as indicated by the TNM classification. Our results demonstrate that loss of p19 INK4D was particularly evident in advanced HCC (stages III and IV), suggesting that decreased p19 ${ }^{\text {INK4D }}$ may promote progression of HCC.

In order to facilitate treatment selection for patients and provide important information for predicting their prognosis, identification of the grade of tumor malignancy is quite important (32). In HCC, clinicopathological prognostic factors, such as tumor size, the number of tumor nodules, capsule formation, capsule invasion, and vascular invasion, have been extensively studied (32). Cell cycle-related molecules, such as proliferating nuclear antigen (PCNA), p2 $1^{\mathrm{CIP} 1}, \mathrm{p} 27^{\mathrm{KIP} 2}$, and p73, have been found to be prognostic biomarkers in various types of human cancer including HCC (33-36). However, there have been no reports on the relationship between $\mathrm{p} 19^{\mathrm{INK} 4 \mathrm{D}}$ expression and the prognosis in HCC. In this study, with regard to prognosis, the survival analysis by the Kaplan-Meier method revealed that p19 ${ }^{\text {INK4D }}$ expression was associated with the overall survival of patients with HCC. It is clinically important that the loss of p1 $9^{\text {INK4D }}$ expression was significantly associated with the short survival of patients with HCC. According to the multivariate analysis, $\mathrm{p} 19^{\mathrm{INK} 4 \mathrm{D}}$ and tumor stage were independent prognostic factors for overall survival. These results suggest that loss of p19 ${ }^{\text {INK4D }}$ in HCC may serve as an indicator of poor prognosis.

In conclusion, loss of $\mathrm{p} 19^{\mathrm{INK} 4 \mathrm{D}}$ expression may play an important role in the process of the differentiation and development of HCC. Furthermore, expression of p19 ${ }^{\text {INK4D }}$ may be an effective predictor of clinical behavior in HCC. In the future, novel therapeutic strategies targeting p19 ${ }^{\text {INK4D }}$ may be useful for preventing the development of HCC. 


\section{Acknowledgements}

We thank Dr Patrick Geraghty for reading the manuscript.

\section{References}

1. Kudo M: Radiofrequency ablation for hepatocellular carcinoma: updated review in 2010. Oncology 78 (Suppl 1): 113-124, 2010.

2. Zhou Y, Zhao Y, Li B, et al: Meta-analysis of radiofrequency ablation versus hepatic resection for small hepatocellular carcinoma. BMC Gastroenterol 10: 78, 2010.

3. Gerdes B, Ramaswamy A, Ziegler A, et al: p16INK4a is a prognostic marker in resected ductal pancreatic cancer: an analysis of p16INK4a, p53, MDM2, an Rb. Ann Surg 235: 51-59, 2002.

4. Kudoh K, Ichikawa Y, Yoshida S, et al: Inactivation of p16/ CDKN2 and p15/MTS2 is associated with prognosis and response to chemotherapy in ovarian cancer. Int J Cancer 99: 579-582, 2002.

5. Nakai S, Masaki T, Shiratori Y, et al: Expression of p57(KIP2) in hepatocellular carcinoma: relationship between tumor differentiation and patient survival. Int J Oncol 20: 769-775, 2002.

6. Ohgi T, Masaki T, Nakai S, et al: Expression of p33(ING1) in hepatocellular carcinoma: relationships to tumour differentiation and cyclin E kinase activity. Scand J Gastroenterol 37: 1440-1448, 2002 .

7. Sandhu C and Slingerland J: Deregulation of the cell cycle in cancer. Cancer Detect Prev 24: 107-118, 2000.

8. Bloom J and Pagano M: Deregulated degradation of the cdk inhibitor p27 and malignant transformation. Semin Cancer Biol 13: 41-47, 2003.

9. Dobashi Y: Cell cycle regulation and its aberrations in human lung carcinoma. Pathol Int 55: 95-105, 2005.

10. Harper JW and Elledge SJ: Cdk inhibitors in development and cancer. Curr Opin Genet Dev 6: 56-64, 1996.

11. Sherr CJ and Roberts JM: Inhibitors of mammalian G1 cyclindependent kinases. Genes Dev 9: 1149-1163, 1995.

12. Hui AM, Sakamoto M, Kanai Y, et al: Inactivation of p16INK4 in hepatocellular carcinoma. Hepatology 24: 575-579, 1996.

13. Sherr CJ: Cancer cell cycles. Science 274: 1672-1677, 1996.

14. Morishita A, Masaki T, Yoshiji H, et al: Reduced expression of cell cycle regulator p18(INK4C) in human hepatocellular carcinoma. Hepatology 40: 677-686, 2004.

15. Sherr CJ: G1 phase progression: cycling on cue. Cell 79: 551-555, 1994.

16. Xia W, Chen JS, Zhou X, et al: Phosphorylation/cytoplasmic localization of p21Cip1/WAF1 is associated with HER2/neu overexpression and provides a novel combination predictor for poor prognosis in breast cancer patients. Clin Cancer Res 10: 3815-3824, 2004.

17. He S, Lu M, Xue W, et al: Phosphorylated p27(Kip1) on Thr157 is an important prognosis in human hepatocellular carcinoma in vivo and in vitro. Med Oncol 28: 94-104, 2011.

18. Duncan TJ, Al-Attar A, Rolland P, Harper S, Spendlove I and Durrant LG: Cytoplasmic p27 expression is an independent prognostic factor in ovarian cancer. Int J Gynecol Pathol 29: 8-18, 2010 .
19. Seki R, Ohshima K, Fujisaki T, et al: Prognostic significance of S-phase kinase-associated protein 2 and p27kip1 in patients with diffuse large B-cell lymphoma: effects of rituximab. Ann Oncol 21: 833-841, 2010.

20. Shen A, Wang Y, Zhao Y, Zou L, Sun L and Cheng C: Expression of CRM1 in human gliomas and its significance in p27 expression and clinical prognosis. Neurosurgery 65: 153-160, 2009.

21. Miyabe S, Okabe M, Nagatsuka H, et al: Prognostic significance of p27Kip1, Ki-67, and CRTC1-MAML2 fusion transcript in mucoepidermoid carcinoma: a molecular and clinicopathologic study of 101 cases. J Oral Maxillofac Surg 67: 1432-1441, 2009.

22. Fukai K, Yokosuka O, Imazeki F, et al: Methylation status of p14ARF, p15INK4b, and p16INK4a genes in human hepatocellular carcinoma. Liver Int 25: 1209-1216, 2005.

23. Desmet VJ, Gerber M, Hoofnagle JH, Manns M and Scheuer PJ: Classification of chronic hepatitis: diagnosis, grading and staging. Hepatology 19: 1513-1520, 1994.

24. Terminology of nodular hepatocellular lesions. International Working Party. Hepatology 22: 983-993, 1995.

25. Yamagata M, Masaki T, Okudaira T, et al: Small hyperechoic nodules in chronic liver diseases include hepatocellular carcinomas with low cyclin D1 and Ki-67 expression. Hepatology 29: 1722-1729, 1999.

26. Hunyady B, Krempels K, Harta G and Mezey E: Immunohistochemical signal amplification by catalyzed reporter deposition and its application in double immunostaining. J Histochem Cytochem 44: 1353-1362, 1996.

27. Matsuda Y and Ichida T: p16 and p27 are functionally correlated during the progress of hepatocarcinogenesis. Med Mol Morphol 39: 169-175, 2006.

28. Bartkova J, Thullberg M, Rajpert-De Meyts E, Skakkebaek NE and Bartek J: Lack of p19 $9^{\mathrm{INK} 4 \mathrm{D}}$ in human testicular germ-cell tumours contrasts with high expression during normal spermatogenesis. Oncogene 19: 4146-4150, 2000.

29. Yang TL, Su YR, Huang CS, et al: High-resolution 19p13.2-13.3 allelotyping of breast carcinomas demonstrates frequent loss of heterozygosity. Genes Chromosomes Cancer 41: 250-256, 2004.

30. Gunduz E, Gunduz M, Ouchida M, et al: Genetic and epigenetic alterations of BRG1 promote oral cancer development. Int J Oncol 26: 201-210, 2005.

31. Gilles L, Guieze R, Bluteau D, et al: p19 ${ }^{\mathrm{INK} 4 \mathrm{D}}$ links endomitotic arrest and megakaryocyte maturation and is regulated by AML-1. Blood 111: 4081-4091, 2008.

32. Takenaka K, Kawahara N, Yamamoto K, et al: Results of 280 liver resections for hepatocellular carcinoma. Arch Surg 131: 71-76, 1996.

33. Niklinski J, Niklinska W, Laudanski J, Chyczewska E and Chyczewski L: Prognostic molecular markers in non-small cell lung cancer. Lung Cancer 34 (Suppl 2): S53-S58, 2001.

34. Tannapfel A, Grund D, Katalinic A, et al: Decreased expression of p27 protein is associated with advanced tumor stage in hepatocellular carcinoma. Int J Cancer 89: 350-355, 2000.

35. Tannapfel A, Wasner M, Krause K, et al: Expression of p73 and its relation to histopathology and prognosis in hepatocellular carcinoma. J Natl Cancer Inst 91: 1154-1158, 1999.

36. Qin LX and Tang ZY: The prognostic molecular markers in hepatocellular carcinoma. World J Gastroenterol 8: 385-392, 2002. 